\title{
Cohnella phaseoli sp. nov., isolated from root nodules of Phaseolus coccineus in Spain, and emended description of the genus Cohnella
}

\author{
Paula García-Fraile, Encarna Velázquez, Pedro F. Mateos, \\ Eustoquio Martínez-Molina and Raúl Rivas
}

Correspondence

Raúl Rivas

raulrg@usal.es
Departamento de Microbiología y Genética, Universidad de Salamanca, 37007 Salamanca, Spain

\begin{abstract}
A bacterial strain designated GSPC1 ${ }^{\top}$ was isolated from root nodules of Phaseolus coccineus in Segovia (Spain). The 16S rRNA gene sequence of this strain showed 95.9 and $94.7 \%$ sequence similarity, respectively, with those of the type strains of Cohnella hongkongensis and Cohnella thermotolerans. Strain GSPC1 ${ }^{\top}$ presented phenotypic, chemotaxonomic and molecular differences with respect to Cohnella species which indicated that it belonged to a different species. The isolate was a Gram-positive, aerobic, sporulated rod, motile by means of peritrichous flagella. The strain was catalase-positive and showed weak oxidase activity. It grew in the

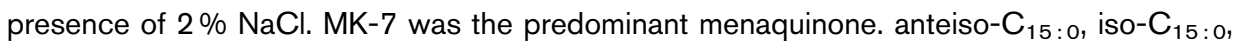
iso- $\mathrm{C}_{16: 0}$ and $\mathrm{C}_{16: 0}$ were the major fatty acids. Major polar lipids were diphosphatidylglycerol, phosphatidylglycerol and phosphatidylethanolamine. The $\mathrm{G}+\mathrm{C}$ content was $60.3 \mathrm{~mol} \%$. The results of this study suggest that isolate $\mathrm{GSPC}^{\top}{ }^{\top}$ should be classified within a novel Cohnella species, for which the name Cohnella phaseoli sp. nov. is proposed, with strain $\mathrm{GSPC}^{\top}{ }^{\top}$ (=LMG $24086^{\top}=$ DSM $19269^{\top}$ ) as the type strain.
\end{abstract}

The scarlet runner or runner bean (Phaseolus coccineus L.) is probably the third most economically important Phaseolus species and the second most important in the human diet. It is a climbing perennial vegetable often grown as an annual crop for dry seeds or immature pod production but in recent years it has also been grown as an ornamental plant in Europe, due to its gaudy inflorescences. There is general agreement that $P$. coccineus establishes symbiotic associations with rhizobial bacteria to form specific structures, root nodules, in which $\mathrm{N}_{2}$ fixation takes place (Souza et al., 1994). However, it is known that not only rhizobial bacteria may be found within root nodules (Trujillo et al., 2006a, b). In the present study, we report on a novel non-nodulating strain from the genus Cohnella, $\mathrm{GSPCl}^{\mathrm{T}}$, isolated from root nodules of $P$. coccineus growing in Granja de San Ildefonso (Segovia, Spain). Several species of Rhizobium are able to nodulate $P$. coccineus in the same soil (García-Fraile et al., 2006).

The genus Cohnella was proposed by Kämpfer et al. (2006) and at present includes three species, Cohnella thermotolerans, C. hongkongensis and C. laeviribosi, and forms a

The GenBank/EMBL/DDBJ accession number for the $16 \mathrm{~S}$ rRNA gene sequence of strain $\mathrm{GSPC} 1^{\top}$ is EU014872.

Electron micrographs and results of 2D TLC of polar lipids of strain GSPC $1^{\top}$ are available as supplementary material with the online version of this paper. homogeneous group within the family Paenibacillaceae. To our knowledge, this is the first report of the association of a bacterium of the genus Cohnella with a leguminous plant.

The root nodules used for the isolation of strain GSPC1 ${ }^{\mathrm{T}}$ were washed several times with sterile distilled water and then surface sterilized in $\mathrm{HgCl}_{2}(2.5 \% \mathrm{w} / \mathrm{v})$ for $2 \mathrm{~min}$. The nodules were rinsed five times with sterile distilled water and then crushed using a sterile glass rod. The homogenized nodule tissue was inoculated on modified yeast extract-mannitol agar (YMA; Vincent, 1970) $\left(1^{-1}: 10 \mathrm{~g}\right.$ mannitol, $1 \mathrm{~g}$ yeast extract, $0.2 \mathrm{~g} \mathrm{~K}_{2} \mathrm{HPO}_{4}, 0.2 \mathrm{~g}$ $\mathrm{MgSO}_{4} \cdot 7 \mathrm{H}_{2} \mathrm{O}, 0.5 \mathrm{~g} \mathrm{NaCl}, 20 \mathrm{~g}$ agar) and the plates were incubated at $28{ }^{\circ} \mathrm{C}$ for 4 days. The cultures used in further phenotypic and molecular studies were purified from a single colony after 2 days incubation at $28{ }^{\circ} \mathrm{C}$ on YMA. The colonies were white, mucoid, translucent and convex on this medium. To test the symbiotic characteristics of the new bacterial isolate, $P$. coccineus and Phaseolus vulgaris plants were inoculated as described by Velázquez et al. (2005), using Rhizobium tropici CIAT $899^{\mathrm{T}}$ as a control. The strain isolated in this study was unable to produce nodules in $P$. coccineus or $P$. vulgaris.

Strain $\mathrm{GSPC1}^{\mathrm{T}}$ was grown in nutrient agar for $48 \mathrm{~h}$ at $22{ }^{\circ} \mathrm{C}$ to check for motility by phase-contrast microscopy with the hanging-drop method. Gram staining was carried out by using the procedure described by Doetsch (1981). 
The flagellation type was determined by electron microscopy after $48 \mathrm{~h}$ incubation of strain $\mathrm{GSPCl}^{\mathrm{T}}$ in nutrient agar at $22{ }^{\circ} \mathrm{C}$. The cells were gently suspended in sterile water and then stained with $0.2 \%$ uranyl acetate and examined at $80 \mathrm{kV}$ with a Zeiss EM 209 transmission electron microscope. Cells of strain $\mathrm{GSPC1}^{\mathrm{T}}$ were Grampositive, rod-shaped $(2.5 \times 0.7 \mu \mathrm{m})$ and motile by means of peritrichous flagella (see Supplementary Fig. S1 available in IJSEM Online); cells of C. thermotolerans, C. hongkongensis and C. laeviribosi are not flagellated (Table 1).

For sequencing of the 16S rRNA gene, DNA extraction was carried out as described previously (Rivas et al., 2001). Amplification of the gene and sequencing were performed according to methods described previously (Rivas et al., 2002). An almost-complete 16S rRNA gene sequence was obtained and compared with those deposited in the GenBank using the BLASTN program (Altschul et al., 1990). Sequences were aligned using CLUSTAL_X software (Thompson et al., 1997) and distances were calculated according to Kimura's two-parameter method (Kimura, 1980). Phylogenetic trees were inferred using neighbourjoining (Saitou \& Nei, 1987) and parsimony analysis (Felsenstein, 1983). Bootstrap analysis was based on 1000 resamplings. The MEGA2 package (Kumar et al., 2001) was used for all analyses.

Comparison of the nearly complete 16S rRNA gene sequence of $\mathrm{GSPCl}^{\mathrm{T}}$ (1429 nt) with sequences held in GenBank indicated that strain $\mathrm{GSPC1}^{\mathrm{T}}$ was phylogeneti-

Table 1. Differential phenotypic characteristics of strain GSPC $1^{\top}$ and type strains of phylogenetically related species

Strains: 1, GSPC1 $^{\mathrm{T}}$ (C. phaseoli sp. nov.); 2, C. thermotolerans CCUG $47242^{\mathrm{T}}$ (data from Kämpfer et al., 2006); 3, C. hongkongensis HKU3 ${ }^{\mathrm{T}}$ (Kämpfer et al., 2006; Teng et al., 2003); 4, C. laeviribosi RI-39 ${ }^{\mathrm{T}}$ (Cho et al., 2007). +, Positive; -, negative; w, weak; ND, no data available.

\begin{tabular}{|lcccc|}
\hline Characteristic & $\mathbf{1}$ & $\mathbf{2}$ & $\mathbf{3}$ & $\mathbf{4}$ \\
\hline Flagella & + & - & - & - \\
Growth at $55{ }^{\circ} \mathrm{C}$ & - & + & + & + \\
Oxidase & $\mathrm{W}$ & + & + & - \\
$o$-Nitrophenyl- $\beta$-D-galactosidase & - & - & + & + \\
Growth in presence of $2 \% \mathrm{NaCl}$ & + & $\mathrm{ND}$ & $\mathrm{ND}$ & - \\
Assimilation of carbon sources & & & & \\
$\quad$ Gluconate & - & + & + & - \\
L-Rhamnose & - & $\mathrm{W}$ & + & + \\
Galactose & - & + & + & + \\
Sucrose & + & - & - & + \\
Trehalose & + & - & - & + \\
D-Xylose & + & - & - & + \\
Adonitol & - & - & - & + \\
Mannitol & - & - & - & + \\
Sorbitol & - & - & - & + \\
Salicin & + & - & - & $\mathrm{ND}^{*}$ \\
$\quad N$-Acetylglucosamine & + & - & + & $\mathrm{ND}^{*}$ \\
& & & & \\
\hline
\end{tabular}

${ }^{\star}$ Acid production was negative. cally related to members of the genus Cohnella within the phylum Firmicutes. Fig. 1 shows the relationship of strain $\mathrm{GSPC1}^{\mathrm{T}}$ within the genus Cohnella and its nearest phylogenetic relatives based on the neighbour-joining method. Similar results were obtained using the maximum-parsimony method (not shown). The sequence similarity of $\mathrm{GSPC}^{\mathrm{T}}$ to the type strains of $C$. hongkongensis, C. thermotolerans and C. laeviribosi was respectively 95.9, 94.7 and 94.2\%; these relationships were supported by high bootstrap values. These levels of 16S rRNA gene sequence similarity are generally considered sufficient to define a novel species since, in general, organisms that share less than $97.0 \% 16 \mathrm{~S}$ rRNA gene sequence similarity do not show more than $70 \%$ DNA-DNA reassociation (Rosselló-Mora \& Amann, 2001; Stackebrandt \& Goebel, 1994; Stackebrandt et al., 2002); DNA-DNA hybridization was therefore not performed.

DNA for the determination of $\mathrm{G}+\mathrm{C}$ content was prepared according to Chun \& Goodfellow (1995); the G+C content of strain $\mathrm{GSPC1}^{\mathrm{T}}$ was determined by using the thermal denaturation method (Mandel \& Marmur, 1968) as $60.3 \mathrm{~mol} \%$.

Chemotaxonomic analyses were performed by the Identification Service of the DSMZ. Isolate GSPC1 ${ }^{\mathrm{T}}$ was cultivated in tryptic soy broth (Becton Dickinson) for $24 \mathrm{~h}$ at $28{ }^{\circ} \mathrm{C}$ in a rotary shaker $(90$ r.p.m.). Biomass was harvested, washed in distilled water and freeze-dried. Menaquinones and polar lipids were analysed as described by Tindall (1990) and cellular fatty acids were analysed according to the instructions of the Microbial Identification System (MIDI; Microbial ID). Unsaturated menaquinone with seven isoprene units (MK-7) was the predominant isoprenoid quinone $(88 \%)$ found in strain GSPC1 ${ }^{\mathrm{T}}$. MK-6 was also detected $(12 \%)$. This quinone profile is characteristic of species within the family Paenibacillaceae and supports the affiliation of strain $\mathrm{GSPC1}^{\mathrm{T}}$ to the genus Cohnella (Kämpfer et al., 2006). The cellular fatty acid profile of GSPC1 ${ }^{\mathrm{T}}$ was characterized by 15 different fatty acids and consisted predominantly of iso- and anteiso-branched fatty acids. The major fatty acids detected in strain $\mathrm{GSPC1}^{\mathrm{T}}$ were anteiso- $\mathrm{C}_{15: 0}(41.5 \%)$, iso$\mathrm{C}_{15: 0}(14.3 \%)$, iso- $\mathrm{C}_{16: 0}(14.1 \%)$ and $\mathrm{C}_{16: 0}(8.9 \%)$. The fatty acid profile of GSPC $1^{\mathrm{T}}$ differed in the proportions of some fatty acids with respect to the type strains of related Cohnella species (Table 2). Strain GSPC1 ${ }^{\mathrm{T}}$ shared a similar polar lipid profile with $C$. thermotolerans CCUG $47242^{\mathrm{T}}, C$. hongkongensis $\mathrm{HKU}^{\mathrm{T}}$ and C. laeviribosi $\mathrm{RI}-39^{\mathrm{T}}$, made up predominantly of diphosphatidylglycerol, phosphatidylglycerol and phosphatidylethanolamine. Four unknown phospholipids (PL1-PL4) and two unknown aminophospholipids (PN1, PN2) were also detected (Supplementary Fig. S2). Two unknown glycolipids (GL1 and GL2) were detected in very small amounts. The presence of these two glycolipids and aminophospholipid PN1 and the absence of lysylphosphatidylglycerol clearly distinguish strain GSPC1 $^{\mathrm{T}}$ from the remaining species of Cohnella (Kämpfer et al., 2006; Cho et al., 2007). 


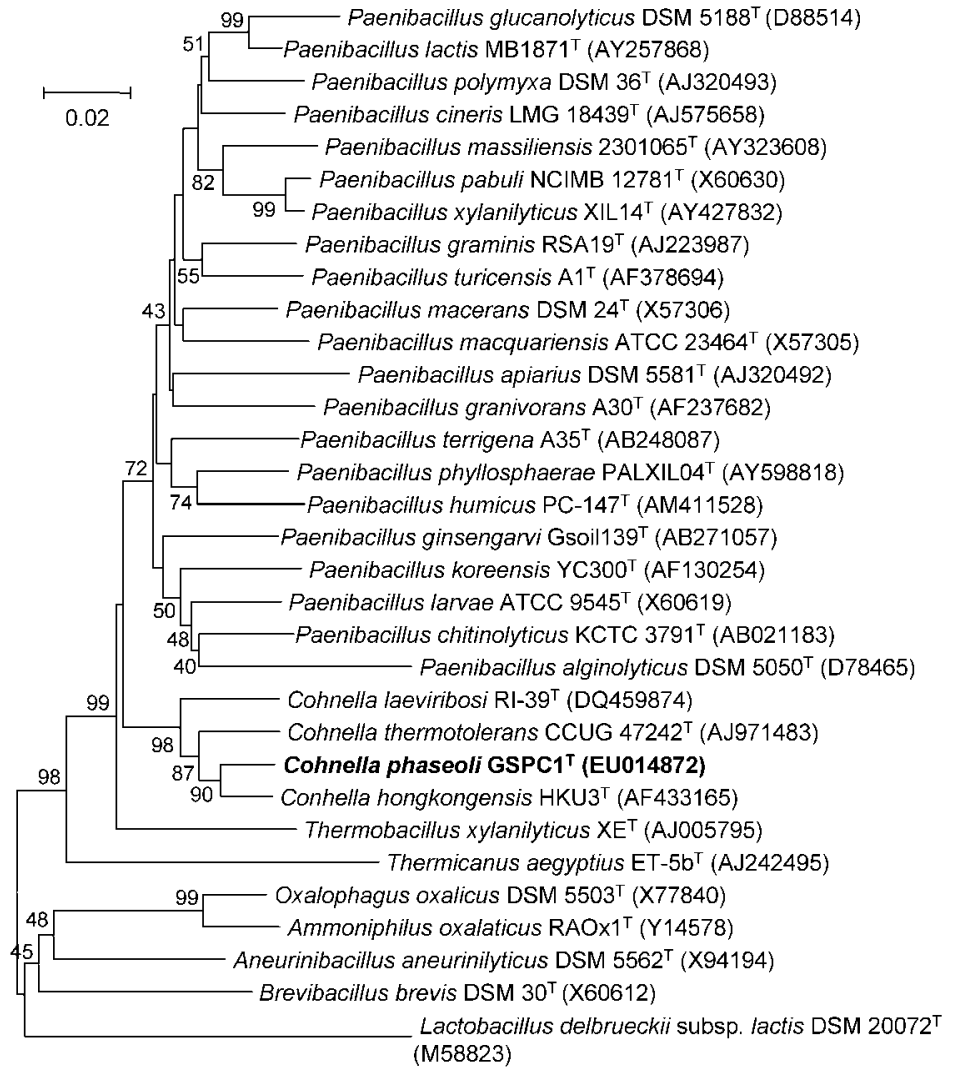

Fig. 1. Comparative sequence analysis of $16 \mathrm{~S}$ rRNA genes from strain $\mathrm{GSPC} 1^{\top}$ and representative species from related genera using the neighbour-joining method. Lactobacillus delbrueckii subsp. lactis DSM $20072^{\top}$ was used as an outgroup. The significance of each branch is indicated by a bootstrap value calculated for 1000 subsets. Bar, 2 substitutions per 100 nucleotide positions.
Phenotypic characterization was performed according to the standard methods described by Claus \& Berkeley (1986) and Logan \& Berkeley (1984) and by using the API $50 \mathrm{CH}$ (with $\mathrm{CHB} / \mathrm{E}$ medium), API 20NE and API 20E systems (bioMérieux) according to the manufacturer's instructions. Acid production from D-glucose, D-xylose, mannitol and L-arabinose, gas production from glucose, acetoin production, the ability to grow in the presence of 2 and $7 \% \mathrm{NaCl}$, nitrate reduction, anaerobic growth and phenylalanine deaminase and caseinase activities were analysed as described by Claus \& Berkeley (1986). Catalase activity was determined by observing bubble formation in a culture after the addition of $3 \%$ hydrogen peroxide. Oxidase activity was determined by oxidation of $1 \%$ tetramethyl $p$-phenylenediamine. Growth at temperatures ranging from 4 to $50{ }^{\circ} \mathrm{C}$ was determined in YED medium $(0.5 \%$ yeast extract, $0.7 \%$ glucose and $2 \%$ agar $)$. Growth at pH 5.7 and 6.8 was tested as described by Claus \& Berkeley (1986), growth at $\mathrm{pH} 7-8$ was tested in YED medium containing $100 \mathrm{mM} \mathrm{Na} \mathrm{NaPO}_{4} / \mathrm{NaH}_{2} \mathrm{PO}_{4}$ and growth at $\mathrm{pH} 9$ and 10 was tested in the same medium containing $100 \mathrm{mM} \quad \mathrm{NaHCO}_{3} / \mathrm{Na}_{2} \mathrm{CO}_{3}$. Differentiating characteristics of strain GSPC1 ${ }^{\mathrm{T}}$ and other Cohnella species are shown in Table 1. The other characteristics determined are given in the species description.

On the basis of phylogenetic, chemotaxonomic and phenotypic data, we propose that isolate $\mathrm{GSPC}^{\mathrm{T}}$ belongs to a novel species of genus Cohnella, Cohnella phaseoli sp. nov.

\section{Description of Cohnella phaseoli sp. nov.}

Cohnella phaseoli (pha.se.o'li. N.L. masc. n. Phaseolus botanical genus name; N.L. gen. n. phaseoli of Phaseolus, referring to the isolation source of the type strain, nodules of Phaseolus coccineus).

Spore-forming rods, $0.7 \mu \mathrm{m}$ wide and $2.5 \mu \mathrm{m}$ long. Grampositive. Motile by means of peritrichous flagella. Round or ovoid spores are formed in slightly swollen sporangia and they are in a central or subterminal position within cells. Colonies on YED are circular, flat, white-cream, opaque and usually $1-3 \mathrm{~mm}$ in diameter after $48 \mathrm{~h}$ growth at $28{ }^{\circ} \mathrm{C}$. The major quinone is MK-7. The main fatty acids are anteiso- $\mathrm{C}_{15: 0}$ and iso- $\mathrm{C}_{16: 0 .}$. Growth occurs from 10 to $45{ }^{\circ} \mathrm{C}$ (optimal growth at $28{ }^{\circ} \mathrm{C}$ ) and $\mathrm{pH} \mathrm{6-8}$ (optimal $\mathrm{pH}$ 7). Aerobic. Weakly positive for oxidase and positive for catalase. Acetoin is produced. The type strain grows in the presence of $2 \% \mathrm{NaCl}$. Nitrate is not reduced to nitrite. $\beta$-Galactosidase is produced, but arginine dihydrolase, indole, lysine decarboxylase, ornithine decarboxylase, urease, tryptophan deaminase, phenylalanine deaminase and hydrogen sulfide are not. Milk coagulation is positive. Gelatinase production is weak. Aesculin is hydrolysed. D-Glucose, Larabinose, maltose, mannose, $\mathrm{N}$-acetylglucosamine, malate 
Table 2. Cellular fatty acid composition of strain $\mathrm{GSPC} 1^{\top}$ and type strains of phylogenetically related species

Strains: 1, C. phaseoli GSPC1 ${ }^{\mathrm{T}}$; 2, C. thermotolerans CCUG $47242^{\mathrm{T}}$ (data from Kämpfer et al., 2006); 3, C. hongkongensis $\mathrm{HKU}^{\mathrm{T}}$ (Kämpfer et al., 2006) 4, C. laeviribosi RI-39 $9^{\mathrm{T}}$ (Cho et al., 2007). ND, Not detected/not reported; tr, trace.

\begin{tabular}{|c|c|c|c|c|}
\hline Fatty acid & 1 & 2 & 3 & 4 \\
\hline \multicolumn{5}{|c|}{ Saturated acids } \\
\hline $\mathrm{C}_{14: 0}$ & 1.8 & 1 & 5 & 1.9 \\
\hline $\mathrm{C}_{15: 0}$ & 5.3 & 1.4 & 8 & 1.3 \\
\hline $\mathrm{C}_{16: 0}$ & 8.9 & 6.6 & 25.3 & 9.2 \\
\hline $\mathrm{C}_{17: 0}$ & 0.5 & ND & 1.2 & $\operatorname{tr}$ \\
\hline iso- $\mathrm{C}_{12: 0}$ & 0.3 & ND & ND & ND \\
\hline iso- $\mathrm{C}_{13: 0}$ & 0.8 & ND & ND & $\operatorname{tr}$ \\
\hline iso- $\mathrm{C}_{14: 0}$ & 2.6 & 2.1 & 2.3 & 3.9 \\
\hline iso- $\mathrm{C}_{15: 0}$ & 14.3 & 3.2 & 8.1 & 11.7 \\
\hline iso- $\mathrm{C}_{16: 0}$ & 14.1 & 45.5 & 11.9 & 40.5 \\
\hline iso- $\mathrm{C}_{17: 0}$ & 3.1 & ND & ND & 2.8 \\
\hline anteiso- $\mathrm{C}_{13: 0}$ & 1.4 & ND & 0.8 & $\operatorname{tr}$ \\
\hline anteiso- $\mathrm{C}_{15: 0}$ & 44.5 & 28.4 & 31.2 & 22.0 \\
\hline anteiso- $\mathrm{C}_{17: 0}$ & 2.3 & 6.7 & 2.6 & 5.8 \\
\hline \multicolumn{5}{|c|}{ Unsaturated acids } \\
\hline iso- $\mathrm{C}_{17: 1}$ & $\mathrm{ND}$ & 1.1 & 1.9 & ND \\
\hline $\mathrm{C}_{14: 1} \omega 5 c$ & $\mathrm{ND}$ & ND & ND & $\operatorname{tr}$ \\
\hline $\mathrm{C}_{16: 1} \omega 7 c$ & 1.9 & ND & ND & ND \\
\hline $\mathrm{C}_{16: 1} \omega 11 c$ & 1.2 & ND & 0.9 & $\operatorname{tr}$ \\
\hline $\mathrm{C}_{17: 1} \omega 6 c$ & $\mathrm{ND}$ & 1 & ND & $\operatorname{tr}$ \\
\hline $\mathrm{C}_{18: 1} \omega 7 c$ & $\mathrm{ND}$ & 4 & $\mathrm{ND}$ & ND \\
\hline
\end{tabular}

and gluconate are assimilated in the API 20NE system. Acid is produced from $\mathrm{D}$-glucose, $\mathrm{D}$ - and $\mathrm{L}$-arabinose, $\mathrm{D}$-ribose, $\mathrm{D}$ xylose, methyl $\beta$-D-xyloside, fructose, mannose, methyl $\alpha$-Dglucoside, $\mathrm{N}$-acetylglucosamine, amygdalin, arbutin, salicin, cellobiose, maltose, lactose, melibiose, sucrose, trehalose, raffinose, starch, glycogen, gentiobiose, turanose and Lfucose in the API $50 \mathrm{CH}$ system. Assimilation of galactose, Lxylose, L-sorbose, L-rhamnose, sucrose, melibiose, erythritol, adonitol, dulcitol, inositol, mannitol, sorbitol, methyl $\alpha$-Dmannoside, inulin, melezitose, xylitol, D-lyxose, D-tagatose, D-fucose, D- and L-arabitol, gluconate, 2-ketogluconate, 5ketogluconate, caprate, propionate, adipate, citrate and phenylacetate is negative. The DNA G $+\mathrm{C}$ content of the type strain is $60.3 \mathrm{~mol} \%$.

The type strain, GSPC1 ${ }^{\mathrm{T}}\left(=\mathrm{LMG} 24086^{\mathrm{T}}=\mathrm{DSM} 19269^{\mathrm{T}}\right)$, was isolated from root nodules of Phaseolus coccineus in Segovia (Spain).

\section{Emended description of the genus Cohnella Kämpfer et al. 2006}

The description is as given by Kämpfer et al. (2006) with the following amendments. Cells are non-motile or motile. Most species are thermotolerant. Predominant polar lipids are diphosphatidylglycerol, phosphatidylglycerol and phosphatidylethanolamine. In addition, lysylphosphatidylglycerol and several unknown phospholipids, unknown aminophospholipids and unknown glycolipids might be present.

\section{Acknowledgements}

This work was supported by the CAICYT-DGES and the JCyL (Spanish Government). We are grateful to the DSMZ staff for chemotaxonomic analyses and to Dr M. Trujillo for her advice on their interpretation.

\section{References}

Altschul, S. F., Gish, W., Miller, W., Myers, E. W. \& Lipman, D. J. (1990). Basic local alignment search tool. J Mol Biol 215, 403-410.

Cho, E. A., Lee, J. S., Lee, K. C., Jung, H. C., Pan, J. G. \& Pyun, Y. R. (2007). Cohnella laeviribosi sp. nov., isolated from a volcanic pond. Int J Syst Evol Microbiol 57, 2902-2907.

Chun, J. \& Goodfellow, M. (1995). A phylogenetic analysis of the genus Nocardia with 16S rRNA sequences. Int J Syst Bacteriol 45, 240-245.

Claus, D. \& Berkeley, R. C. W. (1986). Genus Bacillus Cohn 1872. In Bergey's Manual of Systematic Bacteriology, vol. 2, pp. 1105-1140. Edited by P. H. A. Sneath, N. S. Mair, M. E. Sharpe \& J. G. Holt. Baltimore: Williams \& Wilkins.

Doetsch, R. N. (1981). Determinative methods of light microscopy. In Manual of Methods for General Bacteriology, pp. 21-33. Edited by P. Gerhardt, R. G. E. Murray, R. N. Costilow, E. W. Nester, W. A. Wood, N. R. Krieg \& G. B. Phillips. Washington: American Society for Microbiology.

Felsenstein, J. (1983). Parsimony in systematics: biological and statistical issues. Annu Rev Ecol Syst 14, 313-333.

Garcia-Fraile, P., Velázquez, E., Mateos, P. F., Martínez-Molina, E. \& Rivas, R. (2006). Phylogenetic study of strains nodulating Phaseolus in Spain on the basis of 16S-23S rDNA intergenic spacer sequences. In Abstracts of the 7th European Nitrogen Fixation Conference, poster 102, 22-27 July 2006, Aarhus, Denmark.

Kämpfer, P., Rosselló-Mora, R., Falsen, E., Busse, H.-J. \& Tindall, B. J. (2006). Cohnella thermotolerans gen. nov., sp. nov., and classification of 'Paenibacillus hongkongensis' as Cohnella hongkongensis sp. nov. Int J Syst Evol Microbiol 56, 781-786.

Kimura, M. (1980). A simple method for estimating evolutionary rates of base substitutions through comparative studies of nucleotide sequences. J Mol Evol 16, 111-120.

Kumar, S., Tamura, K., Jakobsen, I.-B. \& Nei, M. (2001). MEGA2: molecular evolutionary genetics analysis software. Bioinformatics 17, 1244-1245.

Logan, N. A. \& Berkeley, R. C. W. (1984). Identification of Bacillus strains using the API system. J Gen Microbiol 130, 1871-1882.

Mandel, M. \& Marmur, J. (1968). Use of ultraviolet absorbance temperature profile for determining the guanine plus cytosine content of DNA. Methods Enzymol 12B, 195-206.

Rivas, R., Velázquez, E., Valverde, A., Mateos, P. F. \& MartínezMolina, E. (2001). A two primers random amplified polymorphic DNA procedure to obtain polymerase chain reaction fingerprints of bacterial species. Electrophoresis 22, 1086-1089.

Rivas, R., Velázquez, E., Willems, A., Vizcaíno, N., Subba-Rao, N. S., Mateos, P. F., Gillis, M., Dazzo, F. B. \& Martínez-Molina, E. (2002). A new species of Devosia that forms a unique nitrogen-fixing root nodule symbiosis with the aquatic legume Neptunia natans (L.f.) Druce. Appl Environ Microbiol 68, 5217-5222. 
Rosselló-Mora, R. \& Amann, R. (2001). The species concept for prokaryotes. FEMS Microbiol Rev 25, 39-67.

Saitou, N. \& Nei, M. (1987). The neighbor-joining method: a new method for reconstructing phylogenetic trees. Mol Biol Evol 4, 406-425.

Souza, V., Eguiarte, L., Avila, G., Cappello, R., Gallardo, C., Montoya, J. \& Piñero, D. (1994). Genetic structure of Rhizobium etli biovar phaseoli associated with wild and cultivated bean plants (Phaseolus vulgaris and Phaseolus coccineus) in Morelos, Mexico. Appl Environ Microbiol 60, 1260-1268.

Stackebrandt, E. \& Goebel, B. M. (1994). Taxonomic note: a place for DNA-DNA reassociation and $16 \mathrm{~S}$ rRNA sequence analysis in the present species definition in bacteriology. Int J Syst Bacteriol 44, 846-849.

Stackebrandt, E., Frederiksen, W., Garrity, G. M., Grimont, P. A., Kämpfer, P., Maiden, M. C., Nesme, X., Rosselló-Mora, R., Swings, J. \& other authors (2002). Report of the ad hoc committee for the reevaluation of the species definition in bacteriology. Int J Syst Evol Microbiol 52, 1043-1047.

Teng, J. L. L., Woo, P. C. Y., Leung, K. W., Lau, S. K. P., Wong, M. K. M. \& Yuen, K. Y. (2003). Pseudobacteraemia in a patient with neutropenic fever caused by a novel paenibacillus species: Paenibacillus hongkongensis sp. nov. Mol Pathol 56, 29-35.
Thompson, J. D., Gibson, T. J., Plewniak, F., Jeanmougin, F. \& Higgins, D. G. (1997). The CLUSTAL_X windows interface: flexible strategies for multiple sequence alignment aided by quality analysis tools. Nucleic Acids Res 25, 4876-4882.

Tindall, B. J. (1990). Lipid composition of Halobacterium lacusprofundi. FEMS Microbiol Lett 66, 199-202.

Trujillo, M. E., Kroppenstedt, R. M., Schumann, P. \& MartínezMolina, E. (2006a). Kribbella lupini sp. nov., isolated from the roots of Lupinus angustifolius. Int J Syst Evol Microbiol 56, 407-411.

Trujillo, M. E., Kroppenstedt, R. M., Schumann, P., Carro, L. \& Martínez-Molina, E. (2006b). Micromonospora coriariae sp. nov., isolated from the roots of Coriaria myrtifolia. Int J Syst Evol Microbiol 56, 2381-2385.

Velázquez, E., Peix, A., Zurdo-Piñeiro, J. L., Palomo, J. L., Mateos, P. F., Rivas, R., Muñoz-Adelantado, E., Toro, N., García-Benavides, P. $\&$ other authors (2005). The coexistence of symbiosis and pathogenicity-determining genes in Rhizobium rhizogenes strains enables them to induce nodules and tumours or hairy roots in plants. Mol Plant Microbe Interact 18, 1325-1332.

Vincent, J. M. (1970). The cultivation, isolation and maintenance of rhizobia. In A Manual for the Practical Study of the Root-Nodule Bacteria, pp. 1-13. Edited by J. M. Vincent. Oxford: Blackwell. 